\title{
Modeling and Comparison of Bodrum Gulets' Hull Forms with Round and Transom Sterns
}

\author{
(1) Bülent İbrahim Turan, (๑) Mehmet Akman \\ Muğla Sitkı Koçman University, Bodrum Maritime Vocational School, Muğla, Turkey
}

\begin{abstract}
Gulets built-in Bodrum region, known as Bodrum gulets, are special and unique yachts with a rich historical background and aesthetic designs. Besides aesthetics, the engineered design is important for such leisure crafts; thus, hull characteristics should be analyzed using a binary approach. In this paper, the hull form characteristics of Bodrum gulets with round and transom sterns are investigated, and parametric models based on geometrical dimensions are developed. In order to obtain reliable results, 20 round stern and 24 transom stern Bodrum gulets are used for the parametric evaluation. Hydrostatic parameters of these models are calculated, and general characteristics such as beaminess and fullness are obtained. Additionally, the Holtrop-Mennen method is also used to estimate the resistance performances of these displacement type hulls. The distinctive or similar characteristics of these types of yachts are presented and compared. Finally, a parametric framework is developed for use in the preliminary design stage of such yachts.
\end{abstract}

Keywords

Bodrum gulet, Round stern, Transom stern, Hull form, Blue voyage

\section{Introduction}

Gulets, Tirhandil, and Transom Stern yachts are the three types of boat found in Bodrum region of Turkey [1]. These exclusive leisure crafts are used in Blue Voyage, including a unique route around Bodrum peninsula. During this voyage, gulets and transom stern types of yachts are mostly preferred due to their wide aft deck and ease of usage [2]. On the other hand, gulets classified in sailing yachts are seen as one of the symbols of Turkish maritime culture with their rich historical background and remarkable aesthetic lines. Wooden gulets are diversified based on personalized designs and constructions with different interior architecture solutions, sail, and rigging design in response to customer demands [3]. Despite their rich historical background and distinctive design, there are very few studies on gulet type yachts in literature. Gammon et al. [4] investigated the resistance, seakeeping, and stability characteristics of Turkish gulets and used a genetic algorithm for the hull form optimization. Sarığlu and Kukner [5] developed a method to estimate the form factor of Bodrum gulets using numerical tools. They stated that the artificial neural network approach is useful in predicting the form factor hull form during the preliminary design stage. A project aimed to research on Turkish gulets and funded by Scientific and Technological Research Council of Turkey was completed [6]. Within this project, Bodrum gulets are analyzed and optimized. Kinacı [7] modeled the Bodrum type schooner yachts using the 1-prismatic coefficient (Cp) method and developed a computer program to be used in the pre-design phase. The recent gulets are designed with round or transom sterns. The shape of the stern influences the functional properties along with the hydrostatics and hydrodynamic characteristics of yachts. Allroth and Wu [8] numerically investigated the hydrodynamic performances of sailing yachts with different shapes of transom sterns, and they stated that box-shaped transom sterns have a smaller wetted surface area, improved righting moment and reduced wave resistance at high Froude numbers. Şireli and Insel [9] analyzed the resistance performance of transom stern crafts and they found that the transom stern

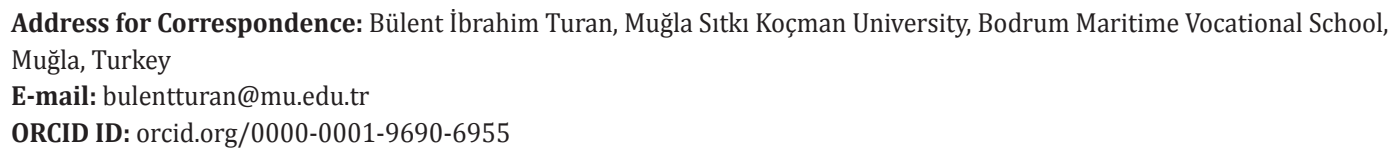

To cite this article: B.I. Turan, and M. Akman, "Modeling and Comparison of Bodrum Gulets' Hull Forms with Round and Transom Sterns." Journal of ETA Maritime Science, vol. 9(2), pp. 120-129, 2021.

${ }^{\circ}$ Copyright 2021 by the Journal of ETA Maritime Science published by UCTEA Chamber of Marine Engineers 
remarkably influences the wave and viscous resistances. Doctors [10] investigated the resistance of transom stern monohulls using regression analyses for the ventilation of the stern and the length of the transom hollow based on the experimental data. According to Papanikolau [11], even though the shape of the stern has no direct relatioship with the form of waterlines or sections, the stern form has an effect on flow to the propeller near to the stern part; in an elliptical stern, flow follows the waterlines whereas in transom stern, it follows the direction of the buttocks.

The numerical studies are focused on transom stern analysis, and the studies on gulets in literature do not consider the sub-classes of Bodrum gulets where significant differences in design are found. In this study, first, the historical background of Bodrum gulets is revealed in the hull form evolution perspective, followed by the studies of geometric, hydrostatic, and hydrodynamic characteristics of Bodrum gulets with round and transom sterns. Twenty round stern and 24 transom stern Bodrum gulets are used for the parametric evaluation, and the Holtrop-Mennen method is used for resistance estimations. The obtained results for two different stern types are compared, a novel framework for the preliminary design and engineering phases of these types of yachts is developed within the statistical base. This is the first study showing the numerical comparison of Bodrum gulets with round and transom sterns and provides a design guide in terms of geometrical and hydrodynamic aspects. Within this perspective, this research aimed to contribute identification and development of the hull form characteristics of gulets specific to Bodrum region.

\subsection{History of Bodrum Gulets}

It is necessary to understand the origin of the term "gulet" and how it came to Turkish to investigate the characteristics of Bodrum gulets. There are various ideas about the emergence of gulet type boats. It is believed that Italians constructed the first gulet in the 1800s [12]. Figure 1 presents transverse section curves of Italian type gulets [13].

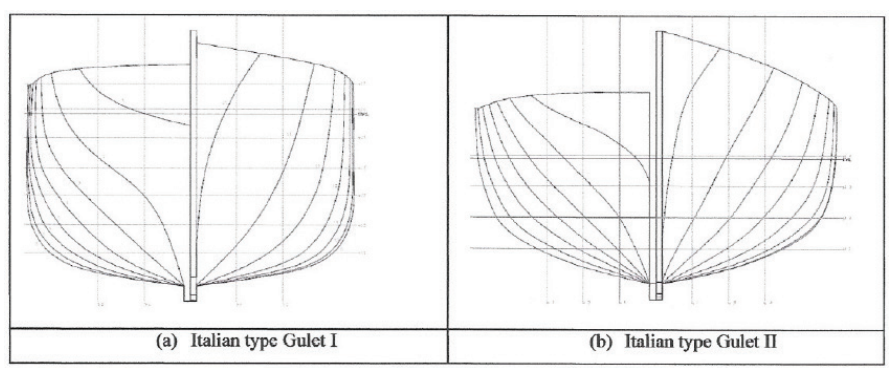

Figure 1. Hull geometry of Italian type gulets [13]
There is general rhetoric that gulets come from schooner type boats. The word "gulet" is defined as a variant of the schooner, specific to the Mediterranean [14]. Uskuna type boats of Dutch origin, known as Schooner in English, are known as Goletta in Italian and Goélette in French [15]. It is also known that the word "goulettes", which means sea swallow in French in the $18^{\text {th }}$ century, was used to describe a sailing was ship [1]. Goletta, which is also known as schooner, is a sailing boat type, which has two masts with equal height or a lower foremast [16].

The first schooner type boat was designed and built by Andrew Robinson in Gloucester, Massachusetts, USA, in 1713 to meet the demand for fast sailing boats in the international tea trade [14]. On the other hand, it is widely thought that schooners were originated in the Netherlands. According to Kükner and Kınacı [17], gulets were originated in the Netherlands; then they spread to England and America before arriving in Europe via Italy and France. The schooner is a two-masted medium-sized sailboat equipped with a bow mast, square rig, and mainmast with fore $[14,18]$.

Thus, both gulet and schooner can be identified based on the rigging type considering all the above statements. On the other hand, the term "gulet" has been used in Turkey for defining the body form designed with a round stern or transom stern [19].

Gulets were widely used in the Mediterranean for various purposes. These types of sailing boats started to appear in the Mediterranean in the late $18^{\text {th }}$ century. Until the gulet "Madonna Annunziata", which had a capacity of 92 barrels and was granted a "Venetian license" by the Senate on December 20,1788, in the Adriatic [20]. Since then, the number of gulets in the Mediterranean increased significantly and spread into many countries. Records stated that 1 gulet was registered in Trieste in 1789, 1 in 1791, and 8 in 1794 [20].

On the other hand, gulets were started in the early 1800 s in Ottoman Empire. It is known that gulets were used for military purposes in the Ottoman Navy in the first half of the $19^{\text {th }}$ century $[14,21]$. According to Tercüman-l Ahval, an early newspaper released in 1860, gulets were used in coastal transportation and carried commercial goods from Mytilene, Chios, Crete, Bodrum, Tripoli, and Canakkale to İstanbul [14]. Based on the special hull form, gulets had high seakeeping performance even in harsh weather and high-volume capacity, enabling them to be used in the transportation of commercial goods.

Over the years, gulets have started in tourism, along with carrying goods, fishing, and sponging in the Aegean Sea $[1,13,17,22]$. In Bodrum region, gulet production has started at the end of the 1950s. Mehmet Uyav and Ziya Güvendiren, 
early boat builders in Bodrum in the years 1958-1959 built two different gulets [23]. Ayaz [24] stated that a $22 \mathrm{~m}$ length "karavoskaro" type boat, called "goletta" by Italians, began to be built in 1958, and the masters from Bodrum improved this type of boat over time, revealing Bodrum gulet. These special yachts are now recognized as an essential component of Blue Voyage. As needs and requirements evolve over time, some minor and major modifications have taken place in interior spaces and hull forms of Bodrum gulets. In Blue Voyage, the demand for larger accommodation spaces on the lower deck led to a sub-category of Bodrum gulets, named Bodrum gulets with transom stern.

Even the term "Bodrum gulet" refers to a type of yacht with elliptical stern form, wine-glass shaped midsection, and a concave stem form. In this research, this original unique form will be labeled as "Bodrum gulet with round stern." The most recently revealed sub-category of Bodrum gulet with transom stern is called "Bodrum gulet with transom stern."

\subsection{Bodrum Gulets with Round Stern}

Generally, Bodrum gulets have two masts: violin-shaped bow and scoop-formed stern [15]. The hull forms of Bodrum gulets have evolved significantly over time due to changes in usage purposes. Figure 2 depicts the lines plan of a modern Bodrum gulet with a round stern.

Having an elliptical stern provides smoother waterlines near the propeller [11]. Therefore, its unique stern form supplies aesthetically satisfactory design and hydrodynamics. However, Bodrum gulets with round stern are not advantageous in aft-lower deck volume compared to Bodrum gulets with a transom stern. Generally, the aft part of lower not suitable for use as a guest cabin, is used for storage, crew area, or galley areas on Bodrum gulets with round stern form.

\subsection{Bodrum Gulets With Transom Stern}

A special yacht type, which is called transom stern yacht in Bodrum, arose by changing the aft side of Bodrum gulets. This type of boat, which appeared in Bodrum after 1985, is a form used for sailboats in Northern Europe for centuries [15]. Transom stern type yacht is a version of the gulet, created by making a flat mirror shape transom instead of a round stern, resulting in the effort to increase the loadbearing capacity and the search for a large working area [19]. Figure 3 shows the lines plan of a Bodrum gulet with a transom stern.

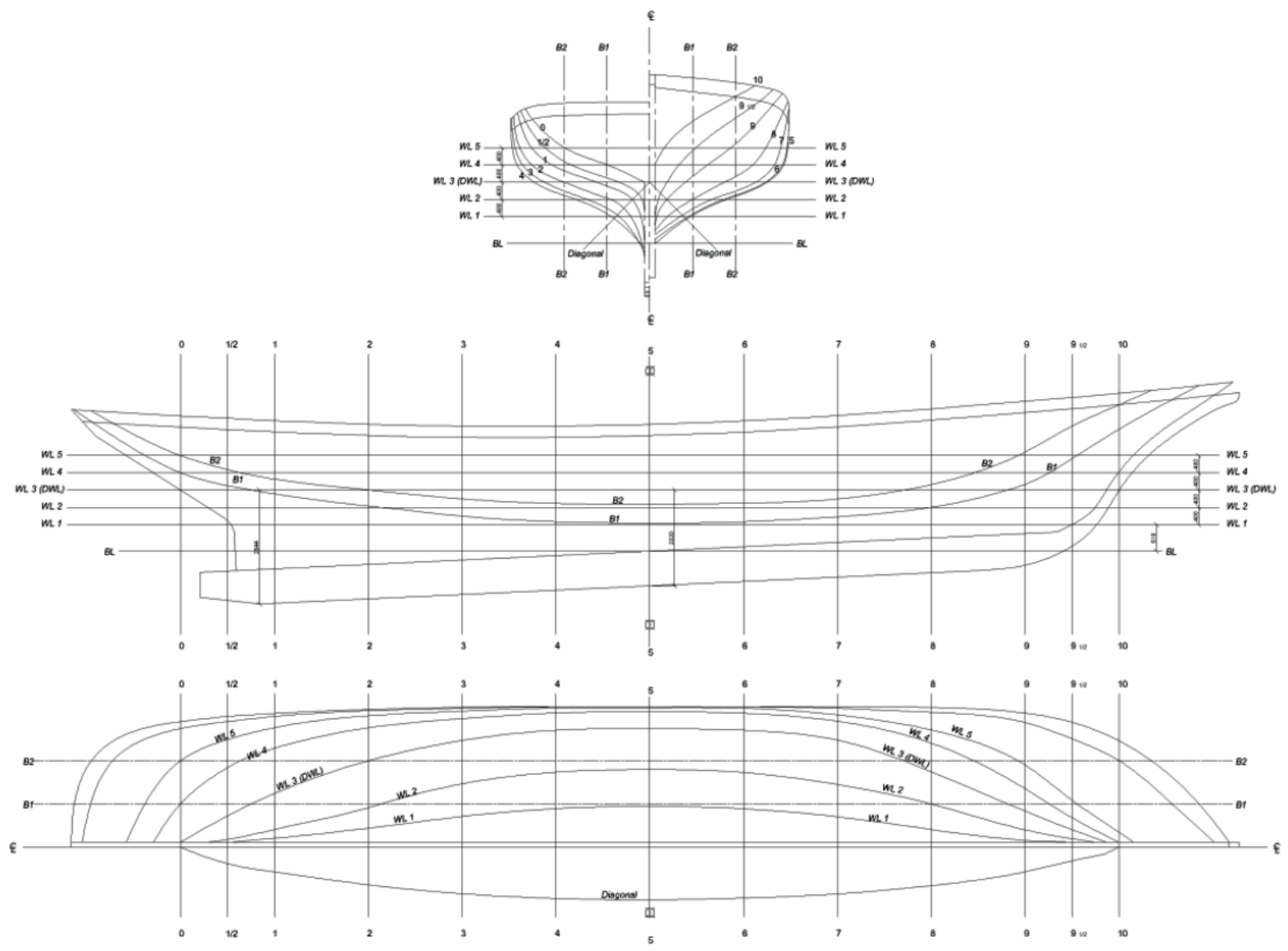

Figure 2. Lines plan of a modern Bodrum gulet with round stern 


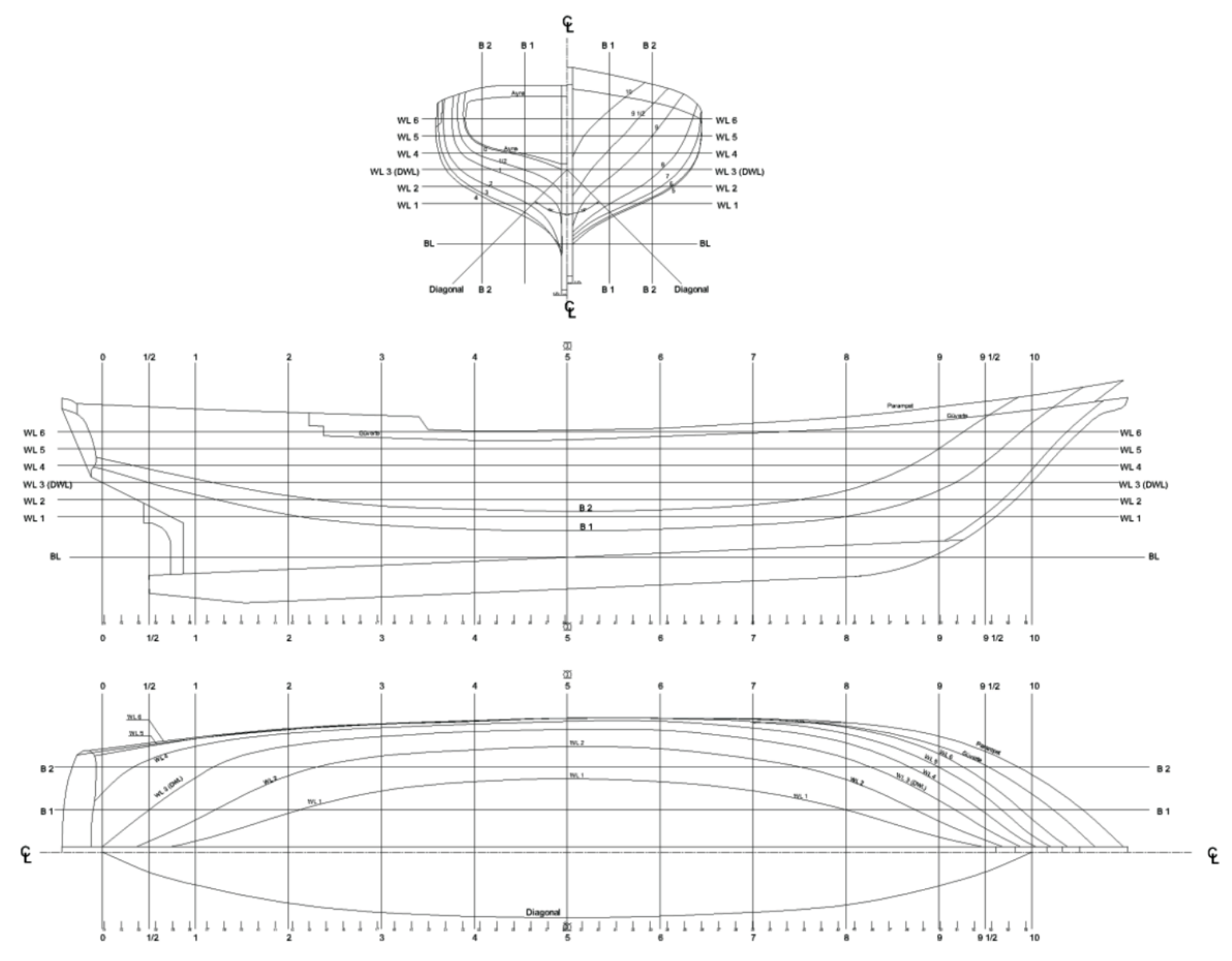

Figure 3. Lines plan of a Bodrum Gulet with transom stern

Except for their aft part of the hull, these yachts with transom stern have a similar hull form as Bodrum gulets with round stern. Transom stern has other advantages such as easier construction and providing additional buoyancy in stern with the possibility of balancing stern trims and disadvantages such as a decrease in propulsion efficiency, increased vibration of the hull, and worse performance in waves when compared to cruiser stern hulls [11]. The main feature that distinguishes the transom stern gulets from the traditional gulets is that the stern sections are not round but rather raised, as in the gulets [25]. On the other hand, transom stern has disadvantages such as increased resistance in low speeds, decreased propulsion efficiency, and high vibration due to clearance limitation between the propeller and the hull [11]. Therefore, a proper guide for the preliminary design phase is required to understand the hydrostatic and geometric parameters of these yachts.

\section{Methodology}

Twenty Bodrum gulets with round stern and 24 Bodrum gulets with transom stern, built-in Bodrum between 1989 and 2020 and still in service, are selected for analyses. In order to increase the accuracy of results, yacht, which are being used only in Blue Voyage and private use, were selected, and daily trip boats were not considered in this research. Figure 4 presents the steps for the investigation and analysis. In this process, 44 Bodrum gulets are analyzed geometrically, and non-dimensional parameters specific to hulls are obtained for curve fitting. In this step, it is important to keep the correlation coefficient (R-square) for dependent variables as high as possible to obtain reliable results [26]. After geometrical evaluation, hydrodynamic characteristics are investigated, and the resistance of 44

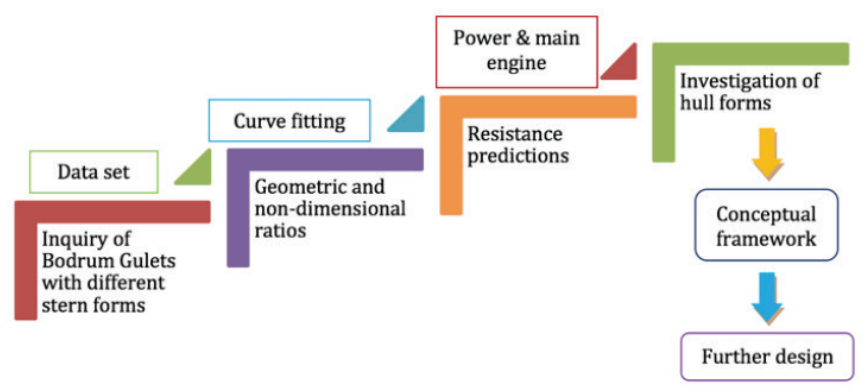

Figure 4. Investigation and analysis steps of the preliminary design phase 
gulet forms is calculated using the Holtrop-Mennen method. After getting resistance values, effective and break horse powers are estimated as summarized in the following equations. Within the obtained data, hull forms are evaluated, and a conceptual design framework for Bodrum gulets with round and transom sterns is created using the dominant parameters.

Hulls of yachts were modeled using the Rhinoceros 3D (Ver. 5) program, and the models were imported to Maxsurf software to obtain hydrostatic and geometric parameters. For comparing resistance characteristics of the selected Bodrum gulets, the resistance module of Maxsurf software was used. The Holtrop-Mennen method was used in resistance prediction because it is based on the regression analysis of different scale model tests and trial data and is a useful tool for displacement type hulls $[27,28]$.

According to the mathematical model $[29,30]$ of the Holtrop-Mennen method, the total resistance of a ship can be calculated as follows (formula 1 is below):

$R_{\text {tot }}=R_{V}+R_{W}$

Where $R_{V}$ refers to the viscous resistance; $R_{W}$ refers to the wave-making resistance. In other words, the total resistance of a ship consists of friction and residual resistances. The viscous resistance is formulated as follows (formula 2 is below):

$R_{V}=(1+k) R_{F}$

Where $R_{F}$ is frictional resistance according to the ITTC1957 formula; the form factor $\mathrm{k}$ is a function of following parameters [30] (formula 3 is below):

$k=f\left(\frac{B}{L}, \frac{T}{L}, \frac{L}{L_{R}}, \frac{L^{3}}{\nabla}, C_{P}, C\right)$

Where $L_{R}$ is the length of run calculated with statistically derived formulation; $\mathrm{c}$ is the coefficient based on the shape of the afterbody which is related with the stern shape coefficient varying with the form types such as V-shaped or U-shaped. The wave resistance is estimated as follows (formula 4 is below):

$$
R_{W}=c_{1} c_{2} c_{3} \nabla \rho g e^{\left(m_{1} F_{n}^{d}+m_{2} \cos \left(\lambda F_{n}^{-2}\right)\right)}
$$

Where $c_{1}, c_{2}, c_{3}, m_{1}, m_{2}$, and $\lambda$ are the coefficients [29] which are the functions of form; $F_{n}$ is the Froude number depends on the velocity of the vessel. By using the total resistance, effective power (EHP) can be estimated for Bodrum gulets. Even EHP does not represent the power of the engine at a given speed due to losses in propulsion and interaction of the flow around the hull, providing a starting point for related calculations [31]. It is possible to obtain shaft horse power approximately by multiplying EHP by 2 [32]. The EHP of the vessel can be calculated as follows (formula 5 is below):

$$
P_{e}=R_{T} V
$$

During analysis, 8, 10, and 12 knots are used for the resistance prediction.

\section{Results}

\subsection{Position of Longitudinal Center of Buoyancy and Longitudinal Center of Flotation (in $\%$ of $\mathrm{L}_{\mathrm{wL}}$ )}

Longitudinal Center of Buoyancy (LCB) is an important parameter used in the weight distribution and consequently in trim calculations in the preliminary design process of a ship. Moreover, this hull form parameter is used in determining wave generation characteristics of the hull. As the LCB shifts to the forepart of the amidship too much, the ship tends to generate more waves in the bow shoulder whereas the LCB shifts to the aft part too much, probability of flow separation and vortices increase [11]. Besides, from the resistance point of view, the LCB/L ratio is a remarkable parameter to estimate the resistance-displacement relationship for a different type hulls [5]. As long as the longitudinal center of gravity does not match with the longitudinal center of buoyancy, a trim occurs on a vessel to match these two points [33]. The minimum, the maximum, and the mean value among the selected yachts' LCB and Longitudinal Center of Flotation (LCF) position in $\%$ are shown in Table 1 . According to the data, there is a difference in LCF as $1.15 \%$, between Bodrum gulets with round stern and Bodrum gulets with transom stern.

\subsection{Hull Form Coefficients}

Hull form coefficients are key parameters to determine the hydrostatic and hydrodynamic characteristics of the yachts. Load, resistance, power, maneuvering, and seakeeping performances are related to these coefficients so that in the design phase of a ship, these parameters should be investigated in detail. Moreover, these coefficients also influence the functionality of yachts which have aesthetic concerns and customerbased requirements. Therefore, the designer and/or the engineer has a comprehension of the yacht's hull characteristics such as beaminess, fineness of the hull ends, fullness of the hull, etc. In this section, important dimensionless hull coefficients of Bodrum gulets with two different stern forms are compared and discussed. Table 1 presents hull form coefficients of 20 Bodrum gulets with round stern and 24 Bodrum Gulets with transom stern. 
Block coefficient describes the fullness of a hull and a dominant factor on weight and resistance. Decrease in block coefficient $\left(\mathrm{C}_{\mathrm{B}}\right)$ has positive effects such as improving seakeeping and decreasing required propulsion power whereas it has negative effects such as increasing curvature in sections [34]. The prismatic coefficient is used to determine fullness or fineness of the hull's ends by considering the immersed volume and midship section area [35]. Midship area coefficient $\left(\mathrm{C}_{\mathrm{M}}\right)$ is used to develop a new design and compare two different boat designs [36]. The waterplane area coefficient is calculated by dividing waterplane area by the multiplication of $\mathrm{L}_{\mathrm{wL}}$ with beam of waterline $\left(\mathrm{B}_{\mathrm{wL}}\right)$. Its value ranges between 0.6 and 0.8 ; the higher values indicate the fullness of the yacht's ends [37]. According to the results, there is a significant difference in $C_{p}$ values calculated as $6.06 \%$ for Bodrum gulets with round stern and Bodrum gulets with transom stern (see Table 1).

\subsection{Length - Beam Correlations}

Length overall $\left(\mathrm{L}_{\mathrm{OA}}\right) /$ Length of waterline $\left(\mathrm{L}_{\mathrm{WL}}\right)$ ratio gives an idea about the overhangs of a yacht in the longitudinal direction. Ledges of a modern hull are decreased for fashion-related reasons and to reduce the longitudinal gyradius for an effective waterline Larsson and Eliasson [38]. In Table 1, the minimum, the maximum, and the mean values for round stern and transom stern Bodrum gulet types are shown. The $\mathrm{L}_{\mathrm{OA}} / \mathrm{L}_{\mathrm{WL}}$ ratio differs by $5.6 \%$ between Bodrum gulets with round stern and Bodrum gulets with transom stern.

Length/beam ratio helps to understand "beaminess" of the boat [39]. Like many other dimensionless ratios, the $\mathrm{L}_{\mathrm{OA}} / \mathrm{B}$ ratio depends on the size of the yacht; it increases as the yacht's length increases because large yachts are less beamy [38]. A beamy boat has the advantages of having a large interior space and high stability in normal angles, but it also has disadvantages of possibly increased difficulty to steer in strong winds and reduced stability in large angles [40]. The studies show that beam and waterline length have significant effect on a boat's wave resistance [41]. Narrowboats are advantageous by providing ease in cruising in waves; however, they are disadvantageous by providing less accommodation in interior spaces and less initial stability when they are compared with beamy boats [40]. Figure 5 depicts $\mathrm{L}_{\mathrm{OA}} / \mathrm{B}$ ratio distribution based on the selected yachts.

As the length of the boat increases, the length/beam ratio's common value shifts from the range of 2.8 and 3.2 to the range of 3.2 and 3.8 [40]. The change of $\mathrm{L}_{\mathrm{OA}} / \mathrm{B}$ ratio is similar for both stern forms, as shown in Figure 5.

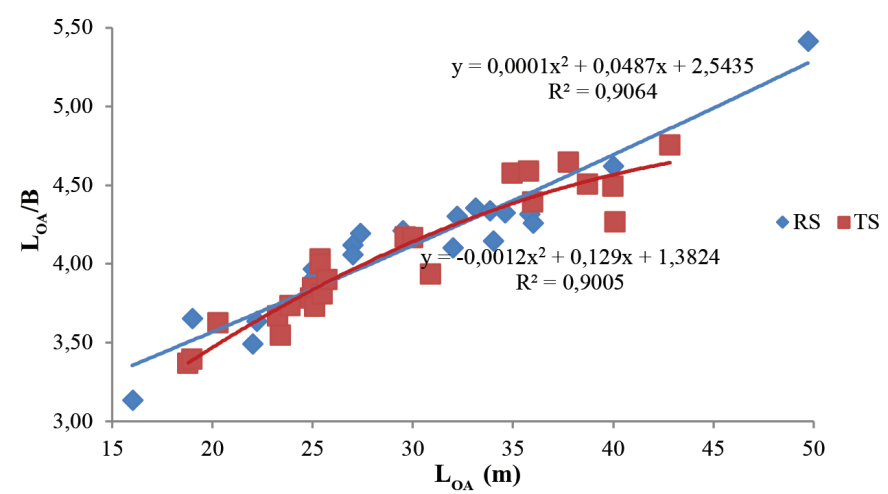

Figure 5. $L_{O A}-L_{O A} / B$ ratio distribution of gulets with round and transom sterns

RS: Round stern, TS: Transom stern, $L_{O A}:$ Length overall, B: Beam of the hull

Table 1. Ratio and values obtained from the research for Bodrum gulet with round stern and transom stern

\begin{tabular}{|c|c|c|c|c|c|c|}
\hline \multirow{2}{*}{ Parameters } & \multicolumn{3}{|c|}{ Round Stern } & \multicolumn{3}{|c|}{ Transom Stern } \\
\hline & Min & Mean & Max & Min & Mean & Max \\
\hline LCB $\left(\% \mathrm{~L}_{\mathrm{wL}}\right)$ & 44.49 & 49.73 & 62.96 & 46.95 & 49.70 & 54.58 \\
\hline $\mathrm{Cb}$ & 0.18 & 0.21 & 0.30 & 0.18 & 0.20 & 0.22 \\
\hline $\mathrm{Cp}$ & 0.62 & 0.66 & 0.72 & 0.53 & 0.62 & 0.69 \\
\hline Cwp & 0.68 & 0.73 & 0.79 & 0.65 & 0.71 & 0.76 \\
\hline $\mathrm{L}_{\mathrm{OA}} / \mathrm{L}_{\mathrm{WL}}$ & 1.19 & 1.25 & 1.32 & 1.11 & 1.18 & 1.27 \\
\hline $\mathrm{L}_{\mathrm{OA}} / \mathrm{B}$ ratio & 3.14 & 4.13 & 5.42 & 3.37 & 4.04 & 4.75 \\
\hline $\mathrm{B} / \mathrm{B}_{\mathrm{wL}}$ ratio & 1.00 & 1.10 & 1.20 & 1.03 & 1.09 & 1.21 \\
\hline Disp./length ratio & 174.35 & 205.92 & 271.84 & 133.97 & 190.82 & 252.83 \\
\hline
\end{tabular}




\subsection{Displacement/Length Ratio}

The displacement of hull in transom stern Bodrum gulets is greater than that of round stern due to an increase in volume of the aft along with the waterline length. Figure 6 depicts the change of displacement with respect to overall length.

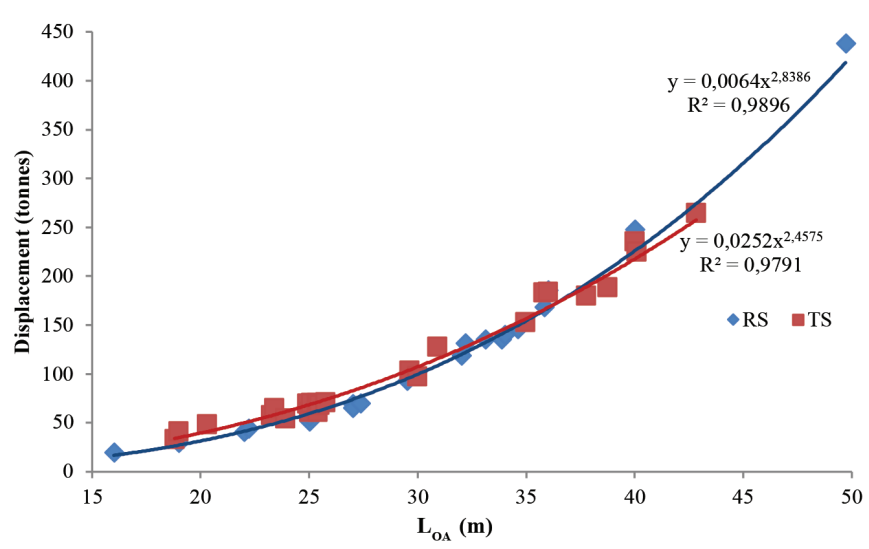

Figure 6. Displacement distribution of Bodrum gulets with different stern forms

RS: Round stern, TS: Transom stern, $L_{O A}$ : Length overall

Moreover, the displacement/length ratio is obtained using the weight and cubic waterline length $\left(0.01 \mathrm{xL}_{\mathrm{wL}}\right)^{3}$ of the vessel $[38,40]$. There are five different displacement descriptions for the yachts according to displacement/ length ratio; ultralight displacement for the ratio between 50 and 100, light displacement for the ratio between 100 and 200, moderate light displacement for the ratio between 200 and 250, moderate high displacement for the ratio of 250 to 300 and heavy displacement for the ratios of 300 or greater [40]. The low displacement/length ratio represents low wave-making resistance by the hull [4]. There is a significant difference in displacement/length ratios of Bodrum gulets with two different stern shapes, as presented in Table 1.

The overall length of typical Bodrum gulets ranges between $18 \mathrm{~m}$ and $25 \mathrm{~m}$; thus, Bodrum gulets with round and transom sterns can be classified in moderate light displacement vessel groups.

\subsection{Resistance Characteristics}

After calculating the resistance performance of Bodrum gulets with two different stern shapes for three different speeds using the Holtrop-Mennen method, the obtained results were combined in a graph to examine the similarities and differences between these two hull forms. Figure 7 shows resistance values of Bodrum gulets with transom stern and round stern for 8,10 , and 12 knots.

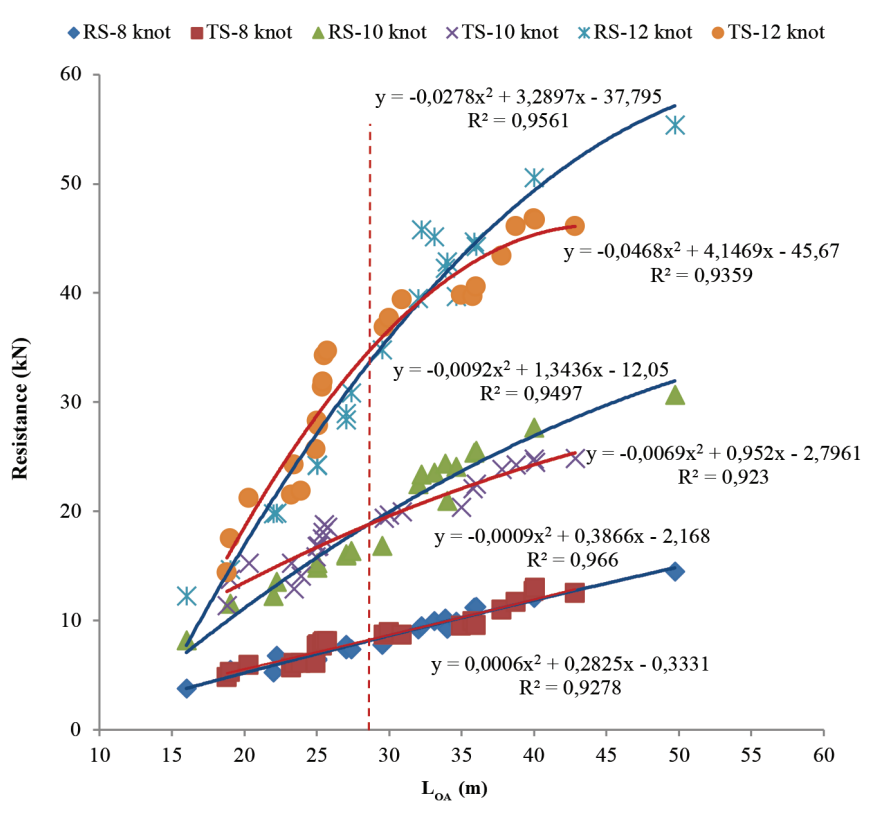

Figure 7. Change of resistance with respect to $L_{O A}$ and vessel speed RS: Round stern, TS: Transom stern, $L_{O A}$ : Length overall

The resistance values of Bodrum gulets with two different stern shapes are similar at 8 knots, as shown in Figure 7. However, compared with transom stern, Bodrum gulets with round stern differ remarkably, especially at 10 knots service speed and at 12 knots maximum speed when the $\mathrm{L}_{\mathrm{OA}}$ is $28 \mathrm{~m}$ or greater. Based on results, Bodrum gulets with transom stern have approximately 15\% less resistance compared to Bodrum gulets with round stern at high speeds when the $\mathrm{L}_{\mathrm{OA}}$ is greater than $28 \mathrm{~m}$. This gap can be explained by differences in $\mathrm{C}_{\mathrm{p}}$ and displacement/ length ratios, which are the function variables affecting viscous resistance in the Holtrop-Mennen method and differences in flow regime due to stern shapes. According to the resistance results, Froude numbers range between 0.25 and 0.40 at speed ranging from 8 and 12 knots. For typical $\mathrm{L}_{\mathrm{OA}}$ values, the resistance of transom stern is higher than that of round stern at the same Froude numbers, based on the difference in flow characteristics at sterns. Sharp corners at transom stern result in flow separation that increases drag [11,42]. Furthermore, 28 $m$ represents a critical $\mathrm{L}_{\mathrm{OA}}$ boundary to be considered in decision making for resistance calculations. $\mathrm{L}_{\mathrm{OA}}$ values below and above $28 \mathrm{~m}$ exhibit significant differences in resistance, particularly at a service speed of 10 knots. Figure 8 presents the estimated engine powers based on the resistance calculations.

The break power of engines installed in typical Bodrum gulets ranges between $280 \mathrm{HP}$ and $450 \mathrm{HP}$ for 12 knots maximum speed, as shown in Figure 8. Similar to the resistance data, the required engine power is higher for 


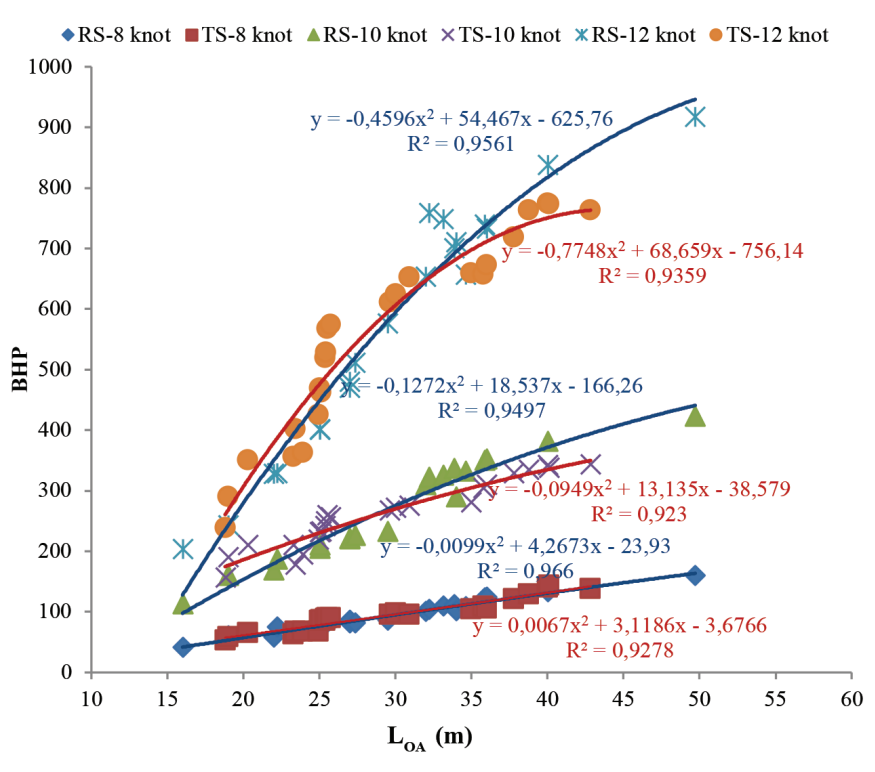

Figure 8. Change of BHP with respect to $L_{O A}$ and vessel speed

RS: Round stern, TS: Transom stern, $L_{O A}$ : Length overall, BHP: Break horse power

transom stern than that of round stern below the overall length of $28 \mathrm{~m}$. Consistent with the resistance values, $28 \mathrm{~m}$ represents a critical threshold in the preliminary design process when a service speed of 10 knots is taken into account. As the $\mathrm{L}_{\mathrm{OA}}$ of Bodrum gulets exceeds this critical value, the ones with transom stern tend to be more advantageous in terms of BHP. In contrast, Bodrum gulets with round stern provide the advantage of resistance and BHP for the $\mathrm{L}_{\mathrm{OA}}$ values lower than $28 \mathrm{~m}$ for 10 and 12 knots, the service speed, and the maximum speed.

\subsection{Conceptual Framework}

A conceptual framework shown in Figure 9 is developed using geometric, hydrostatic, and hydrodynamic data obtained in the previous sections. Using $\mathrm{L}_{\mathrm{OA}^{\prime}}$ it is possible to make a preliminary design of Bodrum gulets with round and transom sterns with this framework.

This framework also provides a guideline in which the designer can obtain $\mathrm{L}_{\mathrm{w}}, \mathrm{B}, \mathrm{B}_{\mathrm{WL}}$, displacement, Keel angle, resistance, hull form coefficients $\left[C_{B}, C_{P}, C_{M}\right.$, waterplane area coefficient $\left(\mathrm{C}_{\mathrm{wP}}\right)$ ], location of LCB and LCF, values of a Bodrum gulet. Besides approximate values and ratios for the stated parameters, it is possible to estimate the desired parameter, enabling flexible design.

According to Figure 9, Bodrum gulets with different stern forms have similar characteristics. The most remarkable difference between these two types is seen in the location of LCF (in $\%$ of $\mathrm{L}_{\mathrm{WL}}$ ), $\mathrm{C}_{\mathrm{P}}$, displacement/length ratio, and $\mathrm{L}_{\mathrm{OA}} /$ $\mathrm{L}_{\mathrm{wL}}$ ratio.

\section{Conclusions}

Bodrum gulets with different stern forms are analyzed in terms of main dimensions driven parameters to reveal the differences and create a framework that can be used in pre-design stage. The following conclusions are drawn for Bodrum gulets with round stern and with transom stern based on the results obtained:

- There are significant differences in the location of LCF (in $\%$ of $\mathrm{L}_{\mathrm{wL}}$ ), $\mathrm{C}_{\mathrm{p}}$, displacement, displacement/length ratio, $\mathrm{L}_{\mathrm{OA}} / \mathrm{L}_{\mathrm{WL}}$ ratio, which directly affect the resistance performance.

- Considering typical overall length of Bodrum gulets, the round stern is more efficient in terms of resistance compared to transom stern. However, especially for the $\mathrm{L}_{\mathrm{OA}}$ greater than $28 \mathrm{~m}$ and for the service speeds and above, Bodrum gulets with transom stern are more favorable in terms of resistance.

- The similarities in hull form parameters such as LCB (in $\%$ of $\left.\mathrm{L}_{\mathrm{WL}}\right), \mathrm{C}_{\mathrm{B}^{\prime}}, \mathrm{C}_{\mathrm{WP}}, \mathrm{C}_{\mathrm{M}}, \mathrm{L}_{\mathrm{OA}} / \mathrm{B}$ confirm that the Bodrum gulets with transom stern are derived from Bodrum gulets with round stern, and these two hull forms types come from the same family.

- Transom stern seems favorable based on their voluminous aft form providing additional buoyancy and accommodation space.

- The developed framework simplifies the decision-making process in the early design stages of Bodrum gulets.

As further research, the sail performances of Bodrum gulets with different stern shapes will be compared by applying different sail \& rigging types, such as schooner and ketch types rigging. In this context, it will be possible to clarify the effects of different stern shapes on the sail performance of Bodrum gulets. Moreover, this research will provide an optimum sail design framework for the Bodrum gulet hull forms by comparing different rig types on these yachts.

\section{Authorship Contributions}

Concept design: B.I. Turan, M. Akman, Data Collection or Processing: B.I. Turan, M. Akman, Analysis or Interpretation: B.İ. Turan, M. Akman, Literature Review: B.İ. Turan, M. Akman, Writing, Reviewing and Editing: B.İ. Turan, M. Akman.

Funding: The authors declared that this study received no financial support. 


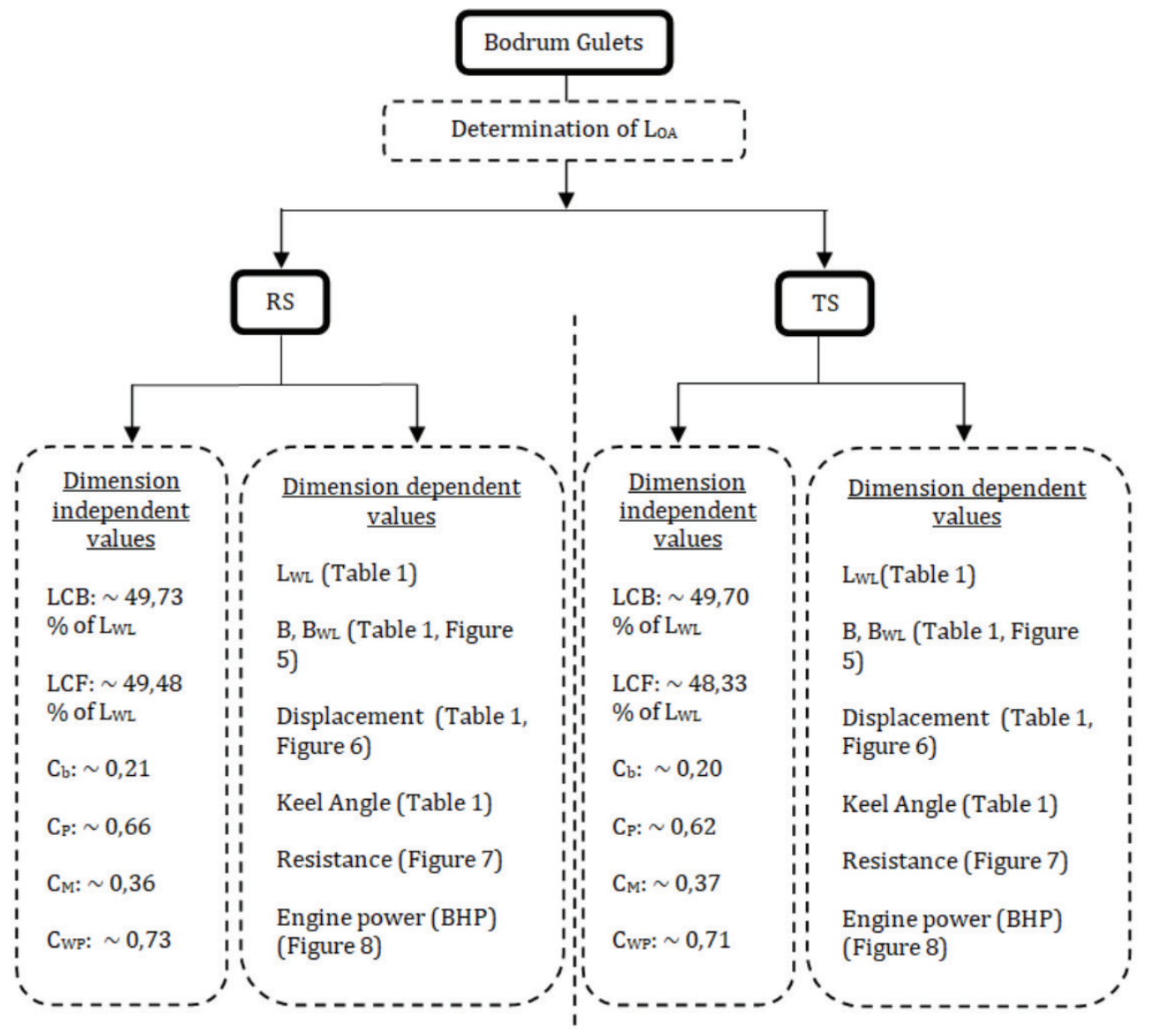

Figure 9. Preliminary design and engineering framework for hull parameters of Bodrum Gulets with RS and TS

RS: Round stern, TS: Transom stern, $L_{O A}$ : Length overall, $L_{W L}$ : Length of waterline, LCB: Longitudinal Center of Buoyancy, LCF: Longitudinal Center of Flotation, $B_{W L}$ : Beam of waterline, $C_{b}$ : Block coefficient, $C_{M}$ : Midship section coefficient, $C_{P}$ : Prismatic coefficient, $C_{W P}$ : Waterplane area coefficient

\section{References}

[1] A. Kükner, “Türk tipi yelkenli tekne gulet," Gemi ve Deniz Teknolojisi, vol. 181, pp. 5-12, 2009.

[2] T. Kuleli et al., "Endemik Bir Turizm Türü Olarak Mavi Yolculuk," 4. Ulusal Deniz Turizmi Sempozyumu, İzmir, Turkey, 2018.

[3] E. Büyükkeçeci and B. I. Turan, "Türkiye'de tekne tasarımında tasarımcının rolünün araştırılması: gulet ve motor yat karşılaştırması," UTAK Ulusal Tasarım, vol. 198, pp. 159-171, 2018.

[4] M. Gammon, A. Kükner, and A. Alkan, Hull Form Optimisation of Performance Characteristics of Turkish Gulets For Charter, Proceedings of the 17th Chesapeake Sailing Yacht Symposium, Annapolis, Maryland, USA, March 2005. Paper: P2005-7 Proceedings., 2005, pp. 79-90.

[5] B.S. Sarıŏlu and A. Kukner, Form Factor Prediction for Turkish type Bodrum Gulets, 3rd International Naval Architecture and Maritime Symposium Proceedings, April 24-25, 2018, İstanbul, Turkey: Ylldız Technical University, 2018. https:// www.researchgate.net/publication/324797161_Form_Factor_ Prediction_for_Turkish_type_Bodrum_Gulets

[6] A. Kükner, et al. Türk Tipi Guletlerin İncelenmesi ve Form Optimizasyonu. TÜBİTAK Araştırma Projesi, Proje No: $106 \mathrm{M} 086$.
[7] Ö.K. Kınacı, Gulet Tipi Yat Serilerinin Matematiksel Modellenmesi, İstanbul: İstanbul Technichal University, 2009.

[8] J. Allroth and T. Wu, "A CFD Investigation of Sailing Yacht Transom Sterns," 2013.

[9] E.M. Şireli and M. Insel, "The Effects of Transom Stern on the Resistance of High Speed Craft," Imam, no. 3, 2000, [Online]. Available: http://www.gidb.itu.edu.tr/staff/insel/ Publications/2000 IMAM.pdf.

[10] L.J. Doctors, "A numerical study of the resistance of transomstern monohulls," Ship Technology Research, vol. 54, pp. 134$144,2007$.

[11] A. Papanikolau, Ship Design-Methodologies of Preliminary Design. Dordrecht: Springer Science+Business Media, Athens: Springer, 2014.

[12] A. Kükner, “Türk Guleti," Gemi ve Deniz Teknolojisi, vol. 174, pp. 7-8, 2007.

[13] B.S. Sarığlu and A. Kükner, Form Factor Prediction for Turkish Type Bodrum Gulets, 3rd International Naval Architecture and Maritime Symposium Proceedings, April 24-25, 2018, İstanbul, Turkey: Ylldız Technical University, 2018, pp. 741-743.

[14] S. Özen, Gemiler Sözlüğü, Istanbul: Denizler Kitabevi, 2017. 
[15] Y. Köyağasığlu, Denizin Kanatlı Perileri Yelkenliler. Istanbul: Naviga Publishings, 2014.

[16] F. Fossati and G. Diana, Principi di Funzionamento di Un'Imbarcazione a Vela. Milano: Schönenfeld \& Ziegler, 2004.

[17] A. Kükner and Ö. K. Kınacı, "Bodrum tipi gulet yat serilerinin matematiksel modellemesi," Gemi ve Deniz Teknolojisi, vol. 181, pp. 13-17, 2009.

[18] S. Nutki, Kamus-i Bahri-Deniz Sözlüğü. Istanbul: Türkiye İş Bankası Kültür Yayınları, 2011.

[19] T. Binder, "BMM Bodrum Maritime Museum-Bodrum Guletleri," Bodrum Deniz Müzesi, [Online]. https://bodrumdenizmuzesi. org/bodrum-guletleri/ (accessed Nov. 2020).

[20] M. Marzari, "L'Arrivo Della Goletta In Acque Italiane," Yacht Digest, Milano, pp. 48-54, 1996.

[21] D. Panzac, Osmanlı Donanması (1572-1923). Istanbul: Türkiye İş Bankası Kültür Yayınları, 2018.

[22] S. Paker and Ö. Özgeçmez, "Gulet tatili ve kadınların gulet tatili satın alma tercihleri üzerine bir araștırma," Dokuz Eylül Üniversitesi Denizcilik Fakültesi Dergisi, vol. 6, pp. 101-113, Dec 2014.

[23] T. Binder, "Bodrum denizciliği ve tekne yapımcılığında giritli göçmenlerin rolü," içinde Ege Araştırmaları I-Batı Anadolu'da Giritliler, Tuncay Ercan Sepetcioğlu ve O. Pullukçuoğlu, Eds. Izmir: Ege University Publishing, 2019, pp. 217-250.

[24] H. Ayaz, Bodrum ve Turizm Sevdam. Istanbul: Destek Yayınları, 2015.

[25] Bodrum Mavi Yolculuk, “Guletler," bodrumlu.com, 2019, [Online]. Available: https://bodrumlu.com/guletler/ (Accessed Sept 2020).

[26] A. Günel, "Regresyon denkleminin başarısını ölçmede kullanılan belirleme katsayısı ve kritiği," Doğuş Üniversitesi Dergisi, vol. 4, pp. 133-140, 2003.

[27] L. Birk, Fundamentals of Ship Hydrodynamics: Fluid Mechanics, Ship Resistance and Propulsion. New Orleans: John Wiley \& Sons, Ltd., 2019.

[28] A.E. Turan, "Türk tipi gulet yatlarının formunun prizmatik katsayıya göre belirlenmesi," Istanbul: Istanbul Technical University, 2009.
[29] J. Holtrop and G. G. J. Mennen, "An approximate power prediction method," Netherlands Ship Model Basin, NSMB, Wageningen, Publication No. 689, International Shipbuilding Progress, ISP, vol. 29, Nr 335, 1982 pp. 166-170, 1982.

[30] A. G. Elkafas, M. M. Elgohary, and A. E. Zeid, "Numerical study on the hydrodynamic drag force of a container ship model," Alexandria Engineering Journal, vol. 58, pp. 849-859, Sept 2019.

[31] E.C. Tupper, Introduction to Naval Architecture, Fourth Edition. Oxford: Elsevier Butterworth-Heinemann, 2004.

[32] D.L. Blount and D. L. Fox, "Small craft power prediction," Marine. Technology, vol. 13, pp. 14-45, Jan 1976.

[33] N.L. Skene, Elements of yacht design. New York: Sheridan House Inc., 2001.

[34] A.F. Molland, The Maritime Engineering Reference Book: A Guide to Ship Design, Construction and Operation. Oxford: ButterworthHeinemann, 2008.

[35] S. Killing and D. Hunter, Yacht Design Explained - A Sailor's Guide to the Principles and Practice of Design, New York: W. W. Norton \& Company, 1998.

[36] E.W. Sponberg, "Articles-Boat design and engineering," Sponberg Yatch Design Inc., 2011, [Online]. Available: https://www. ericwsponberg.com/wp-content/uploads/the-design-ratios. pdf (Accessed Nov. 12, 2020).

[37] A. Mancuso, "Parametric design of sailing hull shapes," Ocean Engineering, vol. 33, pp. 234-246, Feb 2006.

[38] L. Larsson and R. E. Eliasson, Principles of Yacht Design. Camden, Maine: International Marine/McGraw-Hill, 1994.

[39] J. Bakker, "Wetted Surface Area of Recreational Boats-RIVM Report 2017-0116," Bilthoven, 2017.

[40] D. Greene, "Design \& Detail- Looking at the Numbers," Cruising World, 1990. https://www.ericwsponberg.com/wp-content/ uploads/motion-comfort-ratio.pdf.

[41] D.B. Danisman, O. Goren, and S. Calisal, "Resistance Reduction Studies By Means of Increasing the Beam Resistance Reduction Studies By Means of," in GMO SHIPMAR 2017, 2017, no. March 2017, pp. 66-79.

[42] J. O'Dea, D. Jenkins, and T. Nagle, "Flow characteristics of a transom stern ship," David W. Taylor Naval Ship Research and Development Center, pp. 1-57, 1981. 